\title{
Fortification of sago noodles with fish meal skipjack tuna (Katsuwonus pelamis)
}

\author{
Christina LITAAY ${ }^{1}$, Ashri INDRIATI ${ }^{1 \star}$ (D), Nur Kartika Indah MAYASTI ${ }^{1}$
}

\begin{abstract}
Sago is a carbohydrate-producing food commodity in large quantities but has a low protein content. The interaction of protein and carbohydrates in sago noodles is expected to help improve nutritional value. Therefore, this study was conducted to determine the effect of the fortification of skipjack tuna fish meal in increasing the quality of sago noodles. Experimental design using a completely randomized design of one factor, namely the fortification of fish meal with five levels ( $0 \%, 8 \%, 10 \%, 12 \%$, and $14 \%)$. Sago noodle characteristics with the fortification of fish meal were investigated. Result evaluation showed that the fortification of fish meal had the optimum concentration that can be used to increase the nutritional content of sago noodles is fortification of fish meal $14 \%$ with chemical characteristics, namely $2.16 \%$ ash content, $7.70 \%$ protein content, and $0.17 \%$ fat content.
\end{abstract}

Keywords: fish meal; fortification; noodles; sago.

Practical Application: the improved nutritional content of sago-based noodles with fish meal skipjack tuna.

\section{Introduction}

The quality of food consumption of the Indonesian, in general, has not reached an ideal point. This lack is caused by the domination of carbohydrate food groups, especially grains, while coupled with a lack of vegetable and animal protein sources and a lack of vegetables and fruits as fiber as well as vitamins and minerals sources. In Indonesia, rice is still the dominant source for carbohydrates with $98.8 \mathrm{~kg} / \mathrm{cap} /$ year, compared to other sources, such as sago which is still low at $0.5 \mathrm{~kg} / \mathrm{cap} /$ year (Indonesia, 2015). Sago is very potential to be developed and utilized as an alternative food substitute for rice which has high calcium, phosphorus, iron, and carbohydrate content. So far, sago has received less attention than starch, corn and soybean commodities, due to the lack of processed innovation. Starch is an important storage product in plants acting as the main energy source in the human diet. This product is rich in carbohydrates but it has a low protein content. Therefore, it is important to improve the nutritional value of sago noodles. According to Litaay (2012), starch sago has high carbohydrates content of $83.35 \%$ but low protein content of $0.27 \%$. The low sago protein content can be enhanced by the fortification of animal protein derived from fish. Fish is a very good source of animal protein because it has a high nutritional content and is beneficial for health. Consumption of fish is important because fish has a chemical composition with many health benefits (Brito et al., 2019). Marques et al. (2020) reported the Brazil has a level of fish consumption is below the world average. Considering nutritional fish the high, then one of the solution make fish into burger products. Skipjack tuna (Katsuwonus pelamis) is the one commodity that is quite popular in the community and has a high economic value. Skipjack tuna can be used as a source of protein in the manufacture of dry noodles to improve the nutritional value of the product.

Noodles is a product of the most widely consumed by the people of Indonesia, the high consumption of noodles are not offset by the value of the content and quality of nutrition are balanced and would be sure, so the need for enriched or nutrient in the product quality improvement noodles. Noodles are a staple food in many cultures made from unleavened dough which is stretched, extruded, or rolled flat and cut into one of a variety of shapes (Okoye et al., 2008). Noodles are a popular product due to their low cost, ease of transportation, long shelf life, and their nutritional properties, as pasta provides significant amounts of carbohydrates, protein, and complex B vitamins (Fradique et al., 2013). Goes et al. (2016) states that this inclusion is a good way to increase fish intake in the country once people are buying more industrialized and fast food products, easy to prepare and nutritious, but low calorie.

Some research on sago noodles has been carried out including making sago noodles with the use of seaweed flour and the use of curing temperatures (Pujiastuti, 2009; Widaningrum et al., 2005). Low protein content results in efforts to enrich the nutritional value of sago noodles by fortification animal protein. The implementation of the extruded technology and fortification fish meal is required to avoid this issue. Thus, the solution is needed to tackle the 
gluten nutritional value problem of the sago noodles quality. the experiment aimed to analyze the effect fish meal on the cooking time, cooking losses, elasticity, and chemical of sago noodles.

\section{Materials and methods}

\subsection{Materials}

The raw material used was sago flour and fish meal skipjack tuna from Ambon-Maluku, Indonesia (Figure 1). The materials used include water, salt, fish meal, and sago starch as well as chemicals for analysis as selenium, $\mathrm{H}_{2} \mathrm{SO}_{4}$, equates, $\mathrm{NaOH}$, $\mathrm{H}_{3} \mathrm{BO}_{3}, \mathrm{HCl}$, Brom Cresol Green-Methyl Red pink and fat solvent in the form of N-hexane. The specifications of the chemicals used in the study are "Merck". The tools used for making sago noodles is extruder (power 2 pk multilevel screw), digital scales (Fisher scientific), while for the characteristics of sago noodles are ovens (Heraeus instrument), desiccators (csn max), digital scales (Fisher scientific), scanning electron microscope (SEM) JFC-1100, porcelain cups (Duran), ovens (Heraeus instrument), furnaces (Furnace thermolyne), soxhlet flasks (Kimax), filter paper, kjeldahl flasks (Duran and Pyrex) and erlenmeyer flasks (Pyrex).

\subsection{Methods}

\section{Noodle processing diagram}

The processing of noodles is begun with $100 \%$ of sago flour added skipjack fish meal with concentrations of $0 \%, 8 \%$, $10 \%, 12 \%$, and $14 \%$, then added $25 \%$ of water and $2 \%$ of salt, and the batter is mixed with mixer a 15 minute next the starch pre-gelatination process was carried out for 30 minutes, the formation of strands of noodles with extruders and drying room temperature 10 minutes (Figure 2).

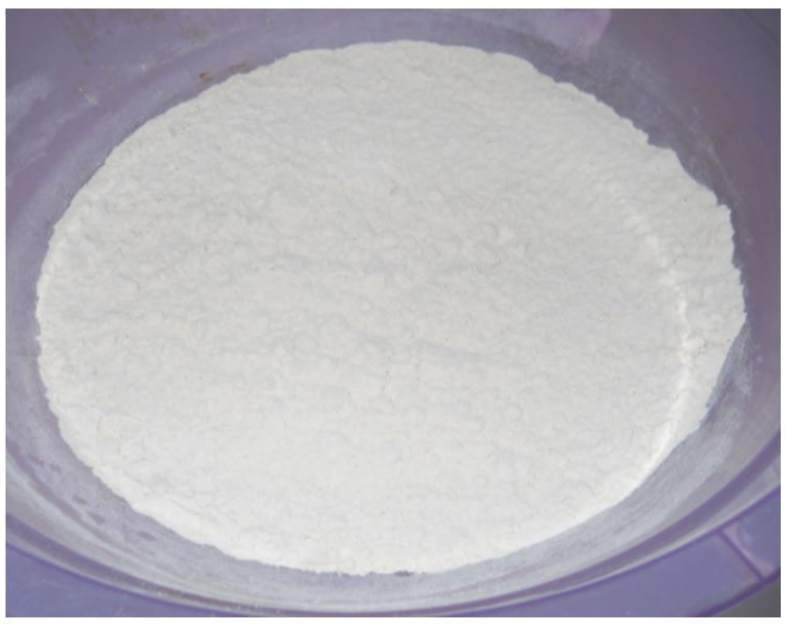

(A)

\section{Cooking time (Collado et al., 2001)}

Noodles $(5 \mathrm{~g})$ were cut into 5 - $\mathrm{cm}$ lengths and cooked in $200 \mathrm{~mL}$ boiling distilled water in a covered beaker. Optimum cooking time was determined by the removal of a piece of noodle every 30 seconds and pressing the noodle between 2 pieces of watch glasses. Optimum cooking is achieved when the center of the noodles becomes transparent or when the noodle is fully hydrated.

\section{Cooking losses (Collado et al., 2001)}

Cooking loss was determined by evaporating to dryness the cooking water and rinse water in a pre-weighed glass beaker in an air oven at $110^{\circ} \mathrm{C}$. The residue was weighed and reported as a percentage of the weight of dry starch noodles before cooking. Rehydration weight was determined by weighing the wet mass after cooked noodles were drained in a strainer for $2 \mathrm{~min}$, and the excess moisture on the surface was wiped with a paper towel. The cooked noodles were stored in a covered Petri dish to minimize drying.

\section{Elasticity (Chen et al., 2002)}

Elasticity was measured using a Texture Analyzer TA-XT2, with the test speed was $1.00 \mathrm{~mm} / \mathrm{s}$ and $5 \mathrm{~kg}$ force. Elasticity (gf) that is a maximum force to break noodles by extention was determined by attaching a noodle strain on a sample.

\section{Proximate analysis (Association of Official Analytical Chemists, 1980)}

The chemical analysis of control noodle sample, commercial noodles, and sago noodles with fortification fish meal were analyzed for moisture, protein, fat, and ash contents by the methods of the Association of Official Analytical Chemist (AOAC). Proximate analysis carried out were moisture, protein, fat, and ash content according to SNI 01-3551-2000 (Indonesian National Standard. (2000).

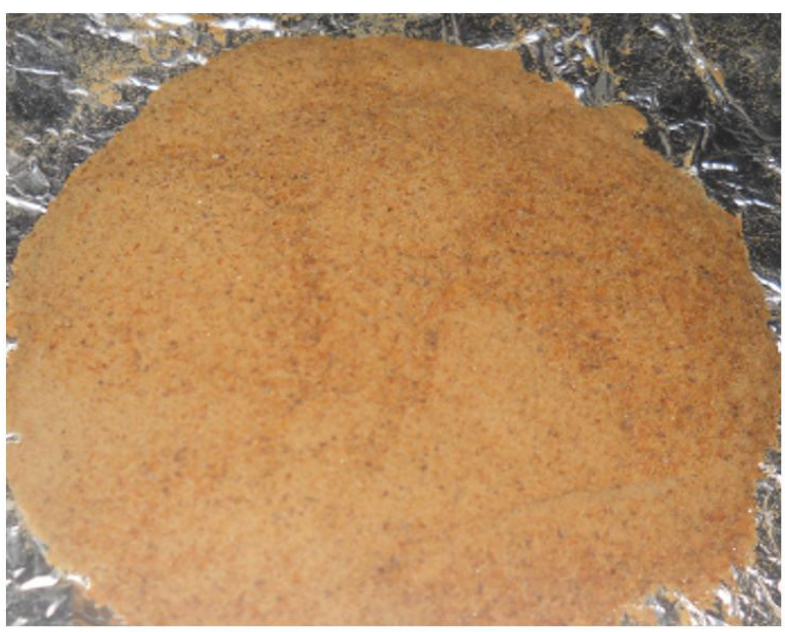

(B)

Figure 1. Sago flour (A), and fish meal (B). 


\section{Sensory evaluation}

All noodle samples were boiled using optimum cooking time. They were evaluated for of color, aroma, taste, and texture of the samples by 30 untrained panelists using nine-point hedonic scales, where $9=$ extremely like and $1=$ extremely dislike.

\section{Statistical analyses}

This study used a simple complete random design with four treatments. The obtained data were tabulated by Ms-Excel

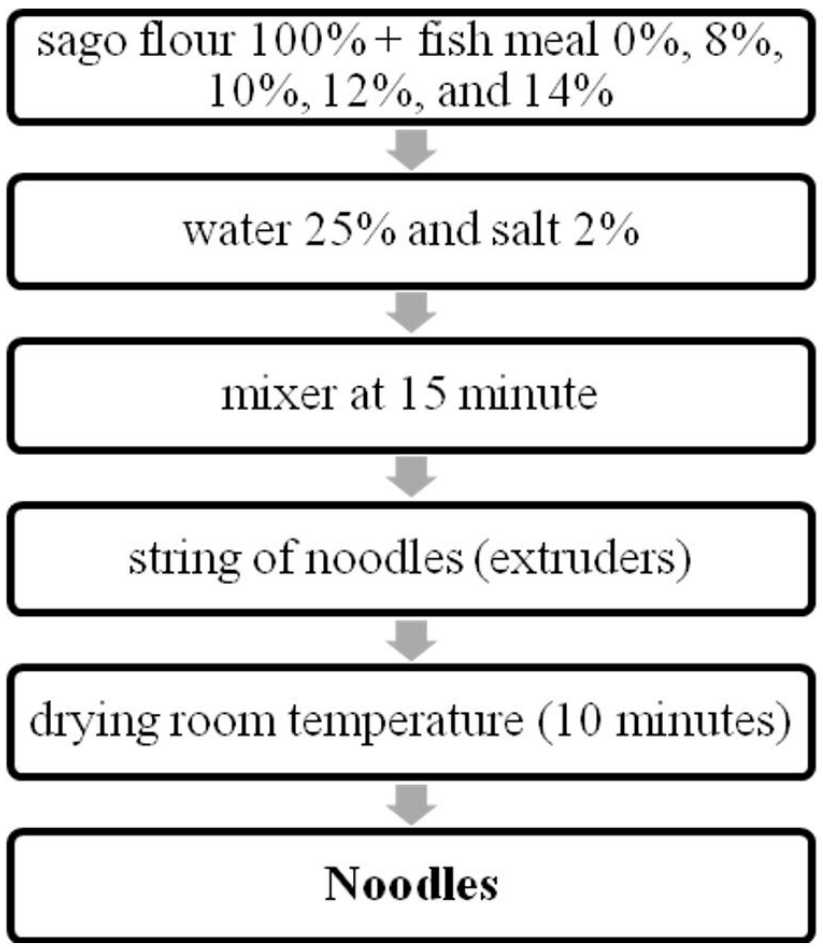

Figure 2. Flow diagram for processing of noodles. Modifikasi CV Putra Santoso (2010). and analyzed. Analyses the effect of fortification fish meal ( $0 \%$, $8 \%, 10 \%, 12 \%$, and $14 \%$ ) on chemical analysis used RAL. The advanced test of BNT performed when ANOVA on treatment had a significant effect $(\mathrm{p}<0.05)$

\section{Result and discussion}

The results of sago starch analysis showed that the carbohydrate content was very high at $85.42 \%$ while the lowest content was $0.95 \%$ fat; water $12.91 \%$; ash $0.30 \%$ and protein $0.42 \%$. High carbohydrate content in sago starch was caused by sago flour as a local food source of carbohydrate which has the potential to be developed to support the implementation of a food diversification program (Lawalata et al., 2004). This is different from skipjack fish meal which has a high protein content of $82.07 \%$ while the lowest content is $1.91 \%$ fat; water $8.12 \%$; ash $3.16 \%$ and carbohydrate $4.74 \%$. The high protein content shows that skipjack tuna is a fishery commodity that has a high nutritional value of protein.

Sago starch which has been used in making sago noodles turned out to have a fairly low protein content, therefore to increase the nutritional content of sago noodles it is necessary to add skipjack fish flour, so it is expected that the protein content in skipjack flour can increase the nutritional value of sago noodles.

\subsection{Physical characteristics of noodles}

\section{Cooking time of noodles}

Cooking time is the length of time for the food to rehydrate so that the texture becomes springy and elastic so that it is ready to be processed again (Winarno, 2004). Noodles cooking time ranges from 7.8 to 9.6 minutes. Noodles with skipjack tuna fish meal fortification $14 \%$ have a faster cooking time of 7.8 minutes (Figure 3).

Cooking time is the length of the food to rehydrate so that the texture becomes springy and elastic so that it is ready to be reprocessed (Winarno, 2004). Cooking time for local

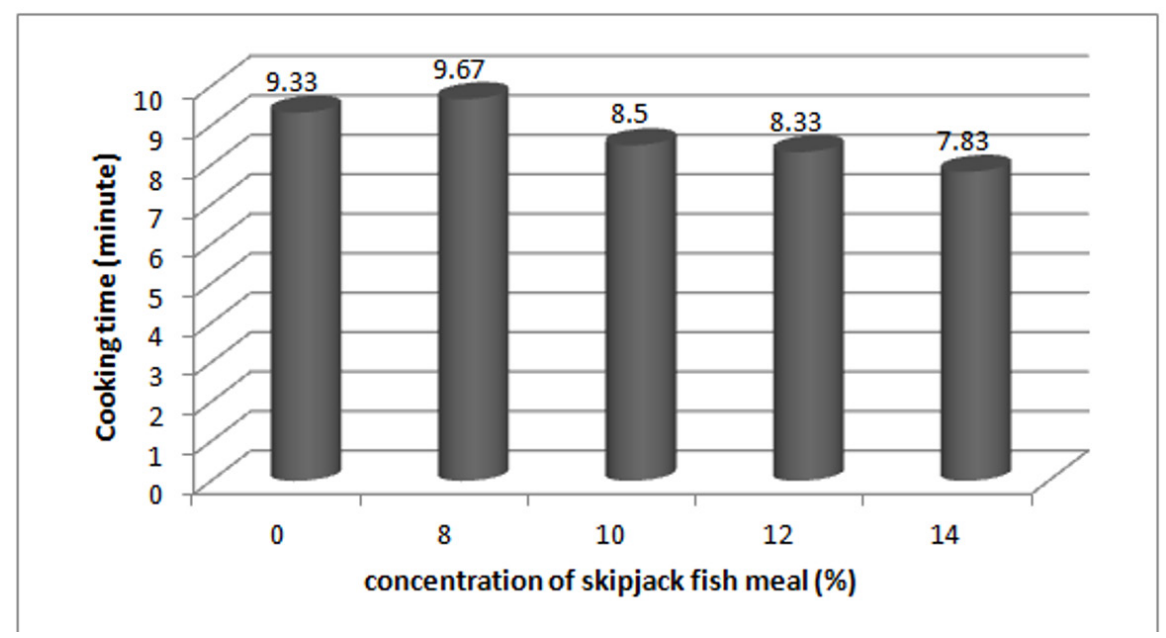

Figure 3. Histogram of noodle cooking time. 
noodles made from sago is around 7.8-9.6 minutes. Noodles with the fortification of $14 \%$ fish meal have a cooking time of 7.8 minutes (Figure 3 ). In this picture, it shows that the increase in fish meal concentration results in decreased cooking time for sago noodles. Thao \& Noomhorm (2011) which were ranging from 8 minutes- 11 minutes. In general, an increase in cooking time decreased the cooking losses and rehydration weight of the noodles.

According to Marsono (1999), the amylose and amylopectin molecules in starch are only physically maintained by the presence of weak hydrogen bonds. With fish meal in the mixture, the bonds between starch molecules will also be disrupted making it easier to penetrate the incoming water. The faster penetration of incoming water, the cooking time is shortened. In the pre-gelatinization process, starch will gelatinized and will absorb water. This gelatinization causes the sago noodles to melt and then forms a thin layer on the surface of the noodles which can affect the rehydration power of the noodles. Cooking time of noodles produced by the fortification of fish meal by $14 \%$ is comparable to the study of Widaningrum et al. (2005), which is 7-9 minutes, where sago noodles are made by mixing dried sago and binder.

\section{Cooking loose noodles}

Cooking losses are the amount of solids contained in dried noodles that come out and dissolve into the water during cooking. The value of noodle cooking losses ranges from $65.53-69.66 \%$ (Figure 4).

Cooking losses are the amount of solids contained in dried noodles that come out and dissolve into the water during cooking. The value of sago noodle-cooking losses ranges from 65.53\%-69.66\% (Figure 4). Amylose content in low sago also plays a role in high cooking losses, because it will reduce the retrograde process in noodles when the noodles are drained. Long drying time also affects the cooking quality of the noodles and long drying can cause the noodles to become brittle. Fragile noodles will break easily and can increase cooking losses marked by the turbidity of the cooking noodle's watercolor. High cooking losses are also caused by the less optimum gelatinized starch matrix in binding non-gelatinized starch (Chen et al., 2002). A high cooking loss gives an expectation of less optimal eating quality. Cooking loss is also of great economic importance to the catering industry (Aaslyng et al., 2003). Cooking losses were, however, mainly influenced by the cooking method (Panea et al., 2008).

\section{Elasticity of noodles}

Elasticity describes the force required by the noodle to return to its original form after the force that causes the noodle to change shape is removed. Elasticity was measured using a TAXT2 texture analyzer. Chen et al. (2002) suggested that the starch gel properties can be used to predict the cooked noodle quality. The result of the measurement shows that the fortification of skipjack fish meal can improve the elasticity of sago noodles. The lowest elasticity was produced by noodles with fish meal fortification at $14 \%$, while the highest elasticity was produced by noodles with fish meal fortification at $8 \%$ (Figure 5).

Elasticity describes the force required by the noodle to return to its original form after the force that causes the noodle to change shape is removed. Elasticity was measured using a TAXT2 texture analyzer. The peak point of positive strength indicates the value of elasticity. The measurement results show that the fortification of skipjack fish flour can increase the elasticity of sago noodles.

The results showed that the elasticity of the noodles produced ranged from 11,571 to 36,588 gf (Figure 5). The lowest elasticity is produced by noodles with the fortification of $14 \%$ fish meal. These results indicate that local sago-based noodles with the fortification of fish meal have a better elasticity compared to instant sago noodles, which is $1,00 \mathrm{gf}$ (Sugiyono et al., 2009).

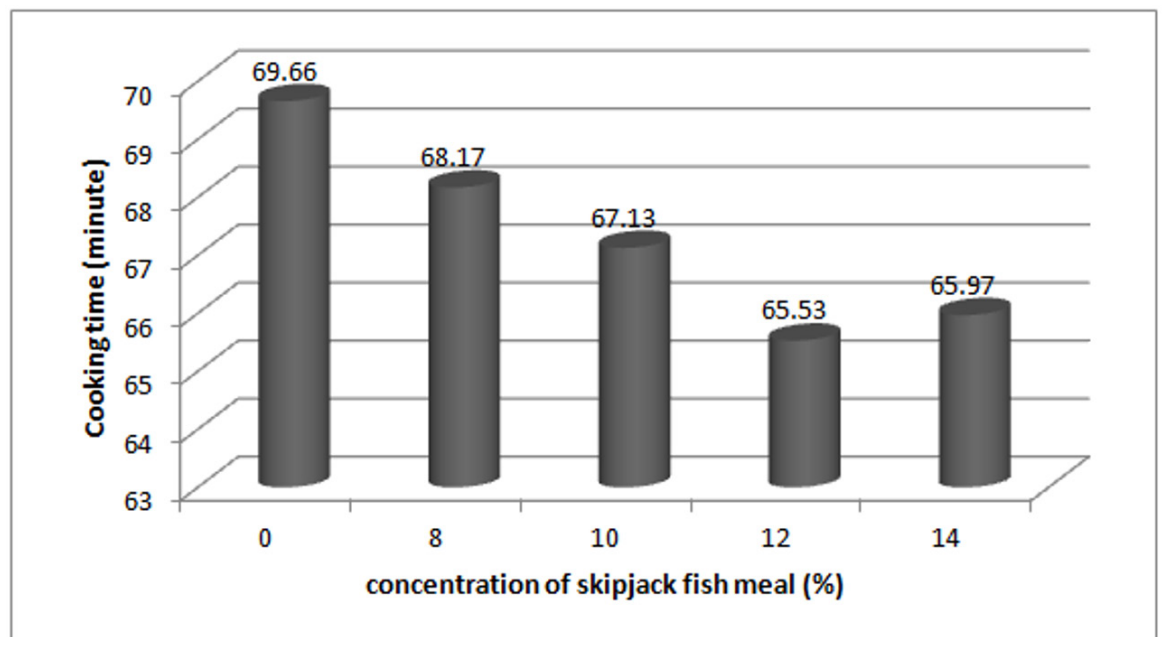

Figure 4. Histogram of average noodle cooking losses. 


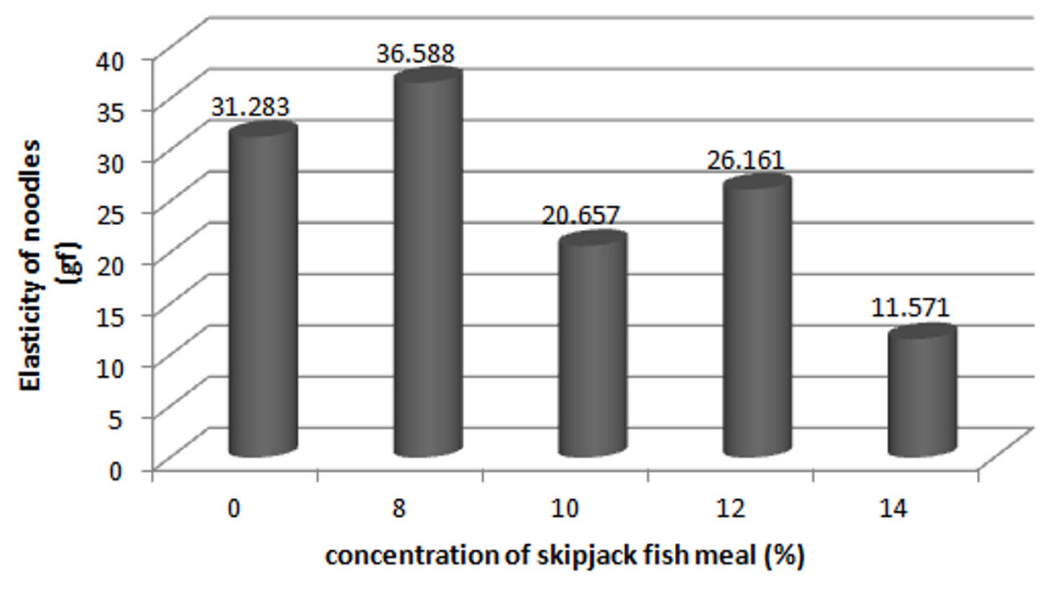

Figure 5. Histogram of the average elasticity of noodles.

\section{Chemical characteristics of noodles}

The characteristics of noodles analyzed in this study were water content, ash, protein, fat, crude fiber, and carbohydrate (by difference). Tests carried out on noodles without the fortification of fish meal and noodles with the fortification of fish meal $8 \%, 10 \%, 12 \%$ and $14 \%$. The results of chemical analysis can be seen in Table 1 .

Based on SNI 01-3551-2000 (Indonesian National Standard, 2000), the noodle water content is lower than the maximum SNI of $14.5 \%$. Noodles do not yet have ash content standards. Noodles with the fortification of $14 \%$ fish meal have higher fat content. This is influenced by the fortification of skipjack fish flour in the dough, thereby increasing the mineral content of the product. Noodles with the fortification of $14 \%$ skipjack fish flour have met the standard with a protein content of 7.70. Noodles with the fortification of $14 \%$ skipjack tuna fish meal have high protein content compared to other noodles. This is due to the process of adding skipjack flour as much as $14 \%$. This sago noodle has higher protein content when compared to the research of Pujiastuti (2009) where sago noodles with the utilization of seaweed flour have protein content ranging from 0.28 to $0.34 \%$. Acoording to Corapci \& Guneri (2020), protein has nutritional value that can enrich various food products or as well as direct consumption.

Based on SNI 01-3551-2000 (Indonesian National Standard, 2000), noodles do not yet have a standard fat and carbohydrate content. Noodle products with the fortification of $14 \%$ fish meal have high-fat content. According to Susanto \& Nurhikmat (2008), the fat content of a product is not only derived from the main standard but also other additives used. Carbohydrate levels of the study showed results ranging from 78.96 to $84.84 \%$. Noodles with the fortification of $14 \%$ fish meal have lower carbohydrate content compared to other noodles, because there is an fortification of fish meal by $14 \%$. The fortification of fishmeal to noodle products causes reduced carbohydrate levels, this provides good nutritional value of protein in noodle products. The addition of a certain substance in food can increase nutritional value, as well research Lira et al. (2019) shown that
Table 1. Chemical characteristics of noodles with the fortification of skipjack fish flour.

\begin{tabular}{lrrrrr}
\hline \multirow{2}{*}{ Parameter } & \multicolumn{5}{c}{ Noodles } \\
\cline { 2 - 6 } & $\mathbf{A}_{\mathbf{0}}$ & \multicolumn{1}{c}{$\mathbf{A}_{8}$} & $\mathbf{A}_{10}$ & $\mathbf{A}_{12}$ & $\mathbf{A}_{14}$ \\
\hline Water (\%) & 11.31 & 11.00 & 11.04 & 10.59 & 11.01 \\
Ash (\%) & 2.05 & 2.06 & 2.11 & 2.13 & 2.16 \\
Protein (\%) & 1.78 & 3.64 & 6.22 & 6.84 & 7.70 \\
Fat (\%) & 0.03 & 0.09 & 0.10 & 0.15 & 0.17 \\
Crude fiber & 1.28 & 1.21 & 1.44 & 1.00 & 1.06 \\
Carbohydrate & 84.84 & 83.21 & 80.53 & 80.29 & 78.96 \\
\hline
\end{tabular}

Table 2. Sensory Characteristics of Noodles.

\begin{tabular}{|c|c|c|}
\hline \multirow[b]{2}{*}{$\begin{array}{c}\text { Sensory Quality } \\
\text { Characteristics }\end{array}$} & \multicolumn{2}{|c|}{ Dry Noodles } \\
\hline & $100 \%$ Sago Flour & $\begin{array}{c}100 \% \text { Sago Flour + } \\
\text { 14\% Skipjack tuna } \\
\text { Fish Meal }\end{array}$ \\
\hline Color & 5 (Neutral) & 5 (Neutral) \\
\hline Aroma & 5 (Neutral) & 5 (Neutral) \\
\hline Taste & 5 (Neutral) & 7 (Likes) \\
\hline Texture & 5 (Neutral) & 7 (Likes) \\
\hline
\end{tabular}

centesimal composition of "Vila Franca" shrimp in natura and with addition of white onion there is an increase in protein content. The results of chemical characteristics show that noodle products made from local sago with the fortification of $14 \%$ fish meal is the best product to be used.

\section{Sensory properties of noodles}

The cooked noodles were evaluated for their sensory quality characteristics of color, aroma, Taste, and texture as 
shown in Table 2. Fortification noodles with $8 \%, 10 \%, 12 \%$, and $14 \%$ are also observed to have equal all attributes of the control noodles $0 \%$.

The results of the panelist's assessment of the noodles color and aroma were known as the median value of 5 (neutral) which means that noodles color ranged normally or was still accepted by panelists. The research of Tanamool et al. (2020) shows that the sensory attributes for odor and color were not significantly affected by the inoculation of Lb. plantarum and MSG, so that there were no significant differences compared to control.

The higher the fortification of skipjack tuna fish meal will produce a darker noodles color. Iman (2017) explains that the color will get darker because of the high use of fish meal, but it does not affect the panelist acceptance rate. The high of fortification skipjack tuna fish meal also not affect the panelist acceptance rate. Noodles with the fortification of $14 \%$ skipjack fish meal have the panelist's assessment of the noodles taste and texture as the median value of 7 (likes). This not corresponding with Iman (2017) statement, which states that the fortification of more nilem fish flour can cause the texture and taste level of the panelists to decline.

\section{Conclusion}

The result of physical, chemical characteristic and sensory properties for sago noodle shows that the fortification of fish meal affect sago noodle. The optimum concentration that can be used to increase the nutritional content of sago noodles is fortification of fish meal $14 \%$ with chemical characteristics, namely $2.16 \%$ ash content, $7.70 \%$ protein content, and $0.17 \%$ fat content.

\section{References}

Aaslyng, M. D., Bejerholm, C., Ertbjerg, P., Bertram, H. C., \& Andersen, H. J. (2003). Cooking loss and juiciness of pork in relation to raw meat quality and cooking procedure. Food Quality and Preference, 14(4), 277-288. http://dx.doi.org/10.1016/S0950-3293(02)00086-1.

Association of Official Analytical Chemists - AOAC. (1980). Official methods of analysis. Virginia: AOAC.

Brito, B. M., Lira, G. M., Pinheiro, A. G. A., Santana, C. M. A. S., \& Amaral, I. L. (2019). Effect of cooking with interesterified margarine in the chemical composition of fish. Food Science and Technology, 39(Suppl. 2), 640-645. http://dx.doi.org/10.1590/fst.29618.

Chen, Z., Sagis, L., Legger, A., Linssen, J. P. H., Schols, H. A., \& Voragen, A. G. J. (2002). Physicochemical properties of sweet potato starches and their application in noodle product. Journal of Food Science, 67(9), 3342-3347. http://dx.doi.org/10.1111/j.1365-2621.2002.tb09589.x.

Collado, L. S., Mabesa, L. B., Oates, C. G., \& Corke, H. (2001). Bihon type noodles from heat-moisture-treated sweet potato starch. Journal of Food Science, 66(4), 604-609. http://dx.doi. org/10.1111/j.1365-2621.2001.tb04608.x.

Corapci, B., \& Guneri, N. (2020). Comparative assessment of nutritional composition and physicochemical properties of fresh, freeze- dried and rehydrated rainbow trout (Oncorhynchus mykiss Walbaum, 1792) mince. Food Science and Technology, 40(Suppl. 1), 163-169. http://dx.doi.org/10.1590/fst.08419.

CV Putra Santoso. (2010). Metode Pembuatan Mie Sagu. AmbonMaluku: CV Putra Santoso.

Fradique, M., Batista, A. P., Nunes, M. C., Gouveia, L., Bandarra, N. M., \& Raymundo, A. (2013). Isochrysisgalbana and Diacronemavl kianum biomass incorporation in pasta products as PUFA's source. Lebensmittel-Wissenschaft + Technologie, 50(1), 312-319. http://dx.doi.org/10.1016/j.lwt.2012.05.006.

Goes, E. S. R., Souza, M. L. R., Michka, J. M. G., Kimura, K. S., Lara, J. A. F., Delbem, A. C. B., \& Gasparino, E. (2016). Fresh pasta enrichment with protein concentrate of tilapia: nutritional and sensory characteristics. Journal of Food Science and Technology, 36(1), 76-82. http://dx.doi.org/10.1590/1678-457X.0020.

Iman, M. (2017). Fortification of Tilapia Meat Against Characteristics of Small Organoleptics and Nutritional Content. Journal of Marine Fisheries, 8(2), 161-167.

Indonesia, Food Security Council. (2015). Strategic food and nutrition policies for 2015-2019. Jakarta: Food Security Agency, Ministry of Agriculture of the Republic of Indonesia.

Indonesian National Standard - SNI. (2000). Instant noodle. Jakarta: National Standardization Agency of Indonesia.

Lawalata, V. N., Budiastra, I. W., \& Haryanto, B. (2004). Improvement nutrition, organoleptic properties and physical of pearl sago with canary fruit fortificational. Agritech, 24(1), 9-16.

Lira, G. M., Lopez, A. M. Q., Nanes, G. M. D. F., \& Silva, F. G. C. (2019). Chemical interaction between white onion, as natural antioxidant, on shrimp stored under freezing. Food Science and Technology, 39(Suppl.2), 535-542. http://dx.doi.org/10.1590/fst.22218.

Litaay, C. (2012). Fortifikasite tepung ikan cakalang (Katsuwonuspelamis) terhadap karakteristik mie sagu (Thesis). Fakultas Perikanan dan Ilmu Kelautan, IPB, Bogor.

Marques, C., Lise, C. C., Lima, V. A., \& Daltoé, M. L. M. (2020). Survival analysis and cut-off point to estimate the shelf life of refrigerated fish burgers. Food Science and Technology, 40(1), 171-177. http://dx.doi.org/10.1590/fst.36918.

Marsono, Y. (1999). Perubahan kadar resistant starch (RS) dan komposisi kimia beberapa bahan pangan kaya karbohidrat dalam pengolahan. Agritech, 19, 124-127.

Okoye, J. I., Nkwocha, A. C., \& Ogbonnaya, A. E. (2008). Production, proximate composition, and consumer acceptability of biscuits from wheat/soybean flour blends. Continent Journal Food Science Technology, 2, 6-13.

Panea, B., Sañudo Astiz, C., Olleta, J. L., \& Civit, D. (2008). Effect of ageing method, ageing period, cooking method, and sample thickness on beef textural characteristics. Spanish Journal of Agricultural Research, 6(1), 25-32. http://dx.doi.org/10.5424/sjar/2008061-291.

Pujiastuti, L.T. (2009). Pemanfaatan tepung rumput laut (Kappaphycus alvarezii) dalam pembuatan mi sagu (skripsi). Jurusan Perikanan, Fakultas Perikanan dan Ilmu Kelautan, IPB, Bogor.

Sugiyono, Thahir, R., Kusnandar, F., Purwani, E. Y., \& Herawati, D. (2009). Peningkatan kualitas mi instan sagu melalui modifikasi heat moisture treatment. In Seminar on Research Results. Bogor, Indonesia: Bogor Agricultural Institute.

Susanto, A., \& Nurhikmat, A. (2008). Pengaruh proses perebusan, pengukusan dan pengepresan terhadap kualitas tepung ikan. In Postharvest 5th year National Seminar: The Results of Fisheries and Marine Research. Yogyakarta, Indonesia: UGM.

Tanamool, V., Hongsachart, P., \& Soemphol, W. (2020). Screening and characterisation of gamma-aminobutyric acid (GABA) producing lactic acid bacteria isolated from Thai fermented fish (Plaa-som) in Nong Khai and its application in Thai fermented vegetables (Som-pak). Food Science and Technology, 40(2), 483-490. http://dx.doi.org/10.1590/fst.05419.

Thao, H. M., \& Noomhorm, A. (2011). Physicochemical properties of sweet potato and mung bean starch and their blends for noodles 
production. Journal of Food Processing \& Technology, 2(01), 1-9. http://dx.doi.org/10.4172/2157-7110.1000105.

Widaningrum, A., Santosa, B. A., \& Endang, Y. P. (2005). Research on the effect of curing temperature on the quality of sago noodles and levels of resistant starch (RS). In National Seminar on Post-Harvest innovative Technologies for Agricultural-Based Industrial Development. Bogor, Indonesia: Balai Besar Penelitian dan Pengembangan Pascapanen Pertanian.

Winarno, F. G. (2004). Food chemistry and nutrition. Jakarta: Gramedia Pustaka Utama. 